\title{
Analisis Faktor-Faktor Pembelian Impulsif pada E-commerce Kecantikan
}

\section{Analysis of Impulsive Purchase Factors on Beauty E-commerce}

\author{
Rania Femi Salsabila ${ }^{1)}$, AMA Suyanto ${ }^{2)}$ \\ ${ }^{1,2)}$ Faculty of Economic and Business, Telkom University, Kota Bandung \\ e-mail korespondensi: raniaaa@student.telkomuniversity.ac.id
}

\begin{tabular}{|l|}
\hline Info Artikel \\
\hline Riwayat Artikel : \\
Diterima: 21 Mei 2021 \\
Disetujui: 15 Oktober 2021 \\
Dipublikasikan: Januari 2022 \\
\hline Nomor DOI \\
10.33059/jseb.v13i1.3568 \\
Cara Mensitasi : \\
Salsabila, R. F., \& Suyanto, \\
AMA. (2022). Analisis faktor- \\
faktor pembelian impulsif pada \\
e-commerce kecantikan. Jurnal \\
Samudra Ekonomi dan Bisnis, \\
13(1), 76-89. doi: 10.33059/ \\
jseb.v13i1.3568.
\end{tabular}

\begin{abstract}
Abstrak
E-commerce kecantikan kerap mengadakan promo yang dapat mendorong orang untuk melakukan pembelian impulsif. Tujuan dari penelitian ini adalah untuk mengetahui faktor-faktor apa saja yang dapat mempengaruhi pembelian impulsif pada e-commerce kecantikan di Indonesia. Penelitian ini menggunakan metode kuantitatif, dengan populasinya adalah konsumen yang pernah membeli di $e$ commerce kecantikan. Jumlah responden sebanyak 385 orang yang berdomisili di kota besar, kota kecil dan kota metropolitan. Teknik multivariat menggunakan analisis faktor eksplorasi. Hasil penelitian menunjukkan bahwa terdapat sepuluh faktor baru yang terbentuk dalam pembelian impulsif di e-commerce kecantikan, yaitu faktor kemudahan dan terorganisir, tren produk, layanan pelanggan, promo, kesenangan, daya tarik, keterbatasan waktu, merek, motivasi berbelanja, dan faktor rekomendasi. Faktor yang dominan di antara faktor-faktor baru tersebut adalah kemudahan dan terorganisir.
\end{abstract}

Kata Kunci: E-commerce Kecantikan, Pembelian Impulsif, Analisis Faktor.

\begin{tabular}{|l|}
\hline Article Info \\
\hline Article History: \\
Received: 21 May 2021 \\
Accepted: 15 October 2021 \\
Published: January 2022 \\
\hline DOI Number : \\
10.33059/jseb.v13i1.3568 \\
How to cite : \\
Salsabila, R. F., \& Suyanto, \\
AMA. (2022). Analisis faktor- \\
faktor pembelian impulsif pada \\
e-commerce kecantikan. Jurnal \\
Samudra Ekonomi dan Bisnis, \\
13(1), 76-89. doi: 10.33059/ \\
jseb.v13i1.3568.
\end{tabular}

\section{Abstract}

Beauty e-commerce often holds promos for people to purchase impulsively. The purpose of this study is to determine what factors can influence impulse buying on beauty e-commerce in Indonesia. This study uses quantitative methods, with the population are consumers who have purchased at beauty e-commerce. The number of respondents was 385 people who domiciles in big cities, small cities and metropolitan cities. The multivariate technique used exploratory factor analysis. The results show that there were ten new factors formed in impulsive purchases in beauty e-commerce, namely ease and organized, product trend, customer service, promo, pleasure, attraction, limited time, brand, shopping motivation, and recommendation factor. The most dominant factor among those new factors is ease and organized.

Keywords: Beauty e-commerce, Impulsive Purchasing, Factor Analysis. 


\section{PENDAHULUAN}

Pada zaman yang sudah modern seperti saat ini, banyak hal dapat dilakukan dengan mudah dan fleksibel. Adanya internet memberikan banyak dampak pada berbagai industri, seperti kemunculan tipe layanan $e$ commerce. E-commerce telah berkembang pesat dan banyaknya pilihan kategori pada $e$ commerce tentu mempermudah masyarakat dalam berbelanja, terutama secara online. Lingkungan belanja website e-commerce semakin menjadi tempat untuk pengalaman yang menyenangkan dan hedonis. Adapun keuntungan yang didapat seperti barangbarang yang lebih murah di e-commerce, pelanggan mencari lingkungan belanja di mana kebutuhan hedonis mereka terpenuhi dan itu adalah tempat yang menyenangkan dan menyenangkan untuk dikunjungi (Nia \& Shokouhyar, 2020). Beberapa kategori pada e-commerce ini mengalami kenaikan pada tahun 2020 jika dibandingkan dengan tahun sebelumnya. Seperti yang ditunjukkan dalam Gambar 1, terdapat pertumbuhan e-commerce berdasarkan kategorinya.

Berdasarkan data pada Gambar 1 itu, industri e-commerce fashion dan kecantikan mengalami peningkatan pada tahun 2020 dari tahun 2019 dengan peningkatan sebesar
$50,7 \%$ dilihat dari pengeluaran masyakarat pada industri tersebut. Hal ini juga dapat dilihat dari meningkatnya jumlah pengeluaran masyarakat untuk belanja online atas barang konsumsi sebesar 23\% untuk tahun 2018 dibandingkan tahun 2017. Perkembangan $e$ commerce merupakan level penetrasi dari internet dan pengguna perangkat mobile yang terus mengalami peningkatan, memungkinkan lebih banyak orang lagi untuk bisa mengakses berbagai platform belanja online, seperti website toko online, aplikasi marketplace, media sosial, dan banyak lagi (Sirclo, 2020).

Dengan adanya e-commerce ini tentu memberikan kemudahan pada konsumen dalam melakukan pembelian secara online. Kemudahan itu bisa ditunjang oleh adanya upaya pemasar memasukkan strategi untuk mendorong pembelian impulsive. Penjualan online melalui website yang terus meningkat terbukti dapat meningkatkan impulse buying, bahkan beberapa website jual beli online hanya mengandalkan strategi mendorong aktivitas impulse buying dalam upaya meningkatkan pendapatannya, seperti dengan cara mengunggah foto produk yang telah dikemas secara menarik agar para pengguna internet dapat melihat dan memunculkan niat beli (Miranda, 2016).

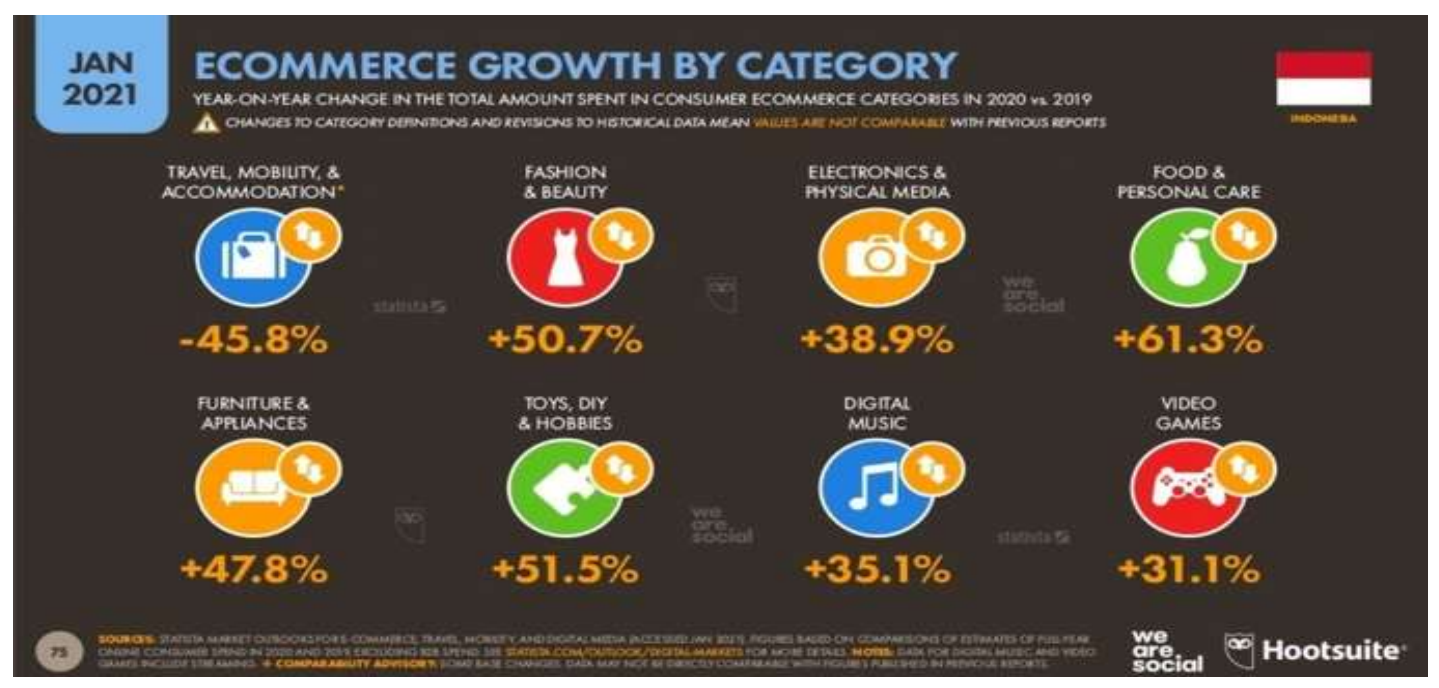

Gambar 1. Pertumbuhan E-commerce berdasarkan Kategori

Sumber: We Are Social and Hootsuite, 2021. 
Tabel 1. Trend Kunjungan Online Situs E-Commerce Kecantikan di Indonesia

\begin{tabular}{clcccc}
\hline No & E-commerce & $\begin{array}{c}\text { Total Visits } \\
\text { Website Bulanan }\end{array}$ & $\begin{array}{c}\text { Total Average } \\
\text { Visit Duration }\end{array}$ & $\begin{array}{c}\text { Pages per } \\
\text { Visit }\end{array}$ & $\begin{array}{c}\text { Total Jumlah } \\
\text { Pengikut Instagram }\end{array}$ \\
\hline 1 & Sociolla & 2,21 juta & $00: 03: 34$ & 3,76 & 921 ribu \\
2 & Beauty Haul Indo & 93,71 ribu & $00: 04: 16$ & 5,01 & 964 ribu \\
3 & Sephora Indonesia & $80,35 \mathrm{ribu}$ & $00: 03: 50$ & 4,84 & $444 \mathrm{ribu}$ \\
\hline
\end{tabular}

Sumber: SimilarWeb.com (diolah), 2021.

Pandemi COVID-19 saat ini membuat orang lebih sering menghabiskan waktu di rumah, memulai kebiasaan baru untuk melakukan apapun dari rumah, termasuk berbelanja secara online. Berbelanja sendiri tentu melibatkan beragam aspek pengalaman dari seorang pembeli yang membutuhkan tingkat interaksi yang substansial di antara pembeli, tenaga penjualan, dan suasana toko (Yoon, 2012). Penelitian yang dilakukan oleh Lee \& Lee (2019) menemukan bahwa ketika konsumen berbelanja di online shopping mall, mereka hanya mengandalkan informasi dan suasana online shopping mall; dimana saat berbelanja di mal online maka efek terapeutik dari faktor terkait kecantikan mal bisa sama pentingnya dengan konteks belanja offline.

Produk kecantikan secara khusus saat ini mulai banyak diminati, tidak terlepas dari semakin sadarnya wanita maupun pria untuk menjaga penampilan. Selain itu, upaya mempercantik diri telah menjadi bagian dari gaya hidup wanita (Salsabila \& Suyanto, 2020). Hal ini memberikan prospek yang baik bagi e-commerce dalam beberapa tahun ke depan. Industri kecantikan tahan terhadap dampak resesi, meskipun kondisi sedang krisis tetapi tidak memengaruhi perempuan maupun lakilaki dalam merawat kulit dan diri.

Pendapat lain menurut laporan dari Euromonitor International, Pasar Masa Depan: ASEAN pada tahun 2020, Indonesia juga disebut sebagai pasar kecantikan yang tumbuh paling cepat di Asia untuk kecantikan dalam hal tingkat pertumbuhan tahunan gabungan (Aninda, 2020). Tabel 1 memapar- kan perbandingan trend kunjungan online pada situs beauty e-commerce di Indonesia.

Ketiga sampel ini dipilih berdasarkan atas jumlah traffic website terbesar serta jumlah followers dari instagram e-commerce kecantikan Indonesia, dimana ketiganya ini memiliki total pengunjung bulanan website ratusan ribu hingga jutaan dalam sebulannya, dengan jumlah total followers instagram yang sudah menembus angka ratusan ribu. Tingginya tingkat total visit tersebut memberikan peluang terhadap pembelian impulsif yang mungkin dilakukan oleh pengunjung, dimana semakin banyak kunjungan pada ketiga situs kecantikan tersebut maka peluang terjadinya pembelian impulsif pun semakin tinggi.

Bila dilihat dari average visit duration, berdasarkan Tabel 1, rata-rata durasi waktu yang dihabiskan seorang pengunjung saat membuka ketiga website e-commerce tersebut yaitu selama kurang dari 3 menit. Data ini juga dapat menegaskan terdapat kemungkinan bahwa pengunjung melakukan pembelian impulsif di antara durasi ini, yang ditunjukan oleh pendapatan pada industri e-commerce kecantikan yang terus meningkat setiap tahunnya (Wibowo, 2020). Semakin kecil visit duration dan page per visit pada website e-commerce, maka diduga bahwa pengunjung pada website e-commerce kecantikan ini tergolong sebagai pelaku pembelian impulsif.

Berdasarkan pemaparan mengenai trend pertumbuhan e-commerce maka faktor-faktor yang dapat membentuk pembelian impulsif pada e-commerce kecantikan di Indonesia masih belum diketahui secara pasti, karena 
mengingat durasi kunjungan dari pengunjung yang dilakukan berdampak pada jumlah pengunjungan situs dan memutuskan untuk keluar dari halaman tersebut karena diduga telah melakukan pembelian impulsif.

\section{Pembelian Impulsif}

Pembelian impulsif adalah aktivitas pembelian yang dilakukan calon konsumen yang sudah berada di dalam toko, dan saat terpapar stimuli eksternal maka muncul keinginan mendesak dalam dirinya untuk segera membeli produk tersebut (Mulyono, 2013; In'am et al., 2016). Pembelian impulsif juga diartikan sebagai sebuah keputusan tidak terencana atau perilaku pembelian spontan untuk membeli suatu produk atau jasa (Laksana \& Suparna, 2015; Finansialku, 2013; Sosianika \& Juliani, 2017). Keputusan membeli terjadi secara tiba-tiba dan seketika saat sebelum melakukan pembelian.

Model yang digunakan pada penelitian ini diadopsi dari beberapa model riset terdahulu, dengan sejumlah modifikasi yang disesuaikan dengan objek analisis. Variabelvariabel yang dipilih pada penelitian ini mengacu pada riset-riset yang dilakukan oleh Utami (2010), Miranda (2016), In'am et al. (2016), Octaprinanta et al. (2013), serta Putri \& Suyanto (2019).

Berdasarkan telaah atas hasil-hasil riset terdahulu tersebut, delapan faktor digunakan pada kerangka penelitian ini. Faktor-faktor WebQual 4.0 efficiency, WebQual 4.0 emotional benefit, dan WebQual 4.0 customer service yang digunakan untuk mengukur seberapa puas pengguna atau konsumen ketika mengakses halaman web e-commerce kecantikan. Faktor-faktor berikutnya adalah shopping lifestyle, kelompok referensi, kepercayaan merek, motivasi belanja hedonis, time pressure, promosi, serta pengaruh situasi yang bisa mendorong pembelian impulsif.

\section{WebQual 4.0}

WebQual 4.0 digunakan sebagai faktor karena penyesuaian dengan objek penelitian ini, dimana e-commerce kecantikan tidak memiliki toko fisik. WebQual 4.0 merupakan suatu pengukuran untuk mengukur kualitas website berdasarkan sejumlah instrumen penelitian yang dapat dikategorikan ke dalam empat variabel, yaitu kegunaan (usability), kualitas informasi (information quality), kualitas interaksi (interaction quality), dan overall impression (Nada \& Wibowo, 2015). Pamungkas \& Saifullah (2019) dalam risetnya juga menjelaskan WebQual4.0 merupakan pengembangan WebQual 1.0 hingga 3.0 serta dikembangkan dan disesuaikan dari metode ServQual.

WebQual 4.0 memiliki empat variabel, yaitu: (1) kegunaan (usability); (2) kualitas layanan (service quality); (3) informasi; dan, keseluruhannya. Ini merupakan pengukur kepuasan konsumen atau pengguna terhadap kualitas situs web e-commerce kecantikan di Indonesia. Putri \& Suyanto (2019) dalam penelitiannya menjelaskan WebQual banyak digunakan untuk menganalisis kualitas situs web, baik website internal (seperti career center, staffsite, studentsite, atau central library) maupun website eksternal (seperti web maskapai penerbangan, dan e-banking).

\section{Shopping Lifestyle}

Japarianto \& Sugiharto (2011) berargumen shopping lifestyle adalah cara hidup yang diidentifikasikan dengan bagaimana cara orang menghabiskan waktu mereka, serta apa yang mereka pikirkan tentang diri mereka sendiri dan juga dunia disekitarnya. Shopping sudah menjadi salah satu lifestyle yang paling digemari, dan untuk memenuhi gaya hidup ini masyarakat rela mengorbankan sesuatu demi mendapatkannya. Kondsi tersebut cenderung mengakibatkan terjadinya impulse buying. 
Levy \& Weitz (2012) berpendapat shopping lifestyle merupakan gaya hidup yang mengacu pada bagaimana seorang individu menjalani kehidupan sehari-hari dengan menghabiskan waktu, uang dan sikap, serta pendapat mengenai kegiatan pembelian mereka tentang keadaan dimana mereka tinggal. Hal tersebut menunjukkan cara hidup seseorang yang lebih memilih mengalokasikan pendapatannya untuk mendapatkan berbagai produk dan layanan yang mampu memenuhi hasrat keinginannya untuk meningkatkan status sosial dalam kehidupan sehari-hari. Lebih jauh, Kosyu et al. (2014) mengungkapkan bahwa shopping lifestyle merupakan gaya hidup seseorang dalam membelanjakan uang, dan ini menjadikan sifat dan karakteristik baru seorang individu.

\section{Kelompok Referensi}

Grewal \& Levy (2018) menyebutkan kelompok referensi ialah satu atau lebih orang-orang yang digunakan individu sebagai dasar perbandingan tentang kepercayaan, perasaan, dan perilaku. Seorang konsumen mungkin memiliki berbagai grup referensi, termasuk keluarga, teman, rekan kerja, atau orang terkenal yang ingin ditiru konsumen. Perreault et al. (2012) menjelaskan kelompok referensi atau grup referensi adalah orangorang yang dilihat seorang individu ketika membentuk sebuah sikap mengenai suatu topik tertentu.

Tiap orang biasanya memiliki beberapa grup referensi untuk berbagai topik. Beberapa dari mereka bertemu tatap muka; yang lain mereka hanya ingin meniru misalnya, pemain atau atlet. Dalam kedua kasus itu, mereka bisa mengambil nilai dari kelompok referensi ini dan membuat keputusan pembelian berdasarkan apa yang mungkin diterima kelompok. Pengaruh referensi lebih kuat untuk produk yang orang lain lihat dan yang terkait dengan status dalam grup. Kardes et al. (2011) menjelaskan kelompok referensi memberikan makna untuk produk oleh asosiasi yang dimiliki oleh konsumen mengenai kelompokkelompok tersebut.

\section{Kepercayaan Merek}

Kotler \& Armstrong (2014) menjelaskan bahwa brand trust adalah harapan akan kehandalan dan intensi baik atas merek. Berdasarkan definisi ini, brand trust merefleksikan dua komponen penting. Pertama, keyakinan konsumen bahwa produk tersebut mampu memenuhi nilai yang dijanjikan; atau dengan kata lain, persepsi bahwa merek itu mampu memenuhi harapan konsumen dengan terpenuhinya janji merek yang pada akhirnya menciptakan customer satisfaction. Kedua, keyakinan konsumen bahwa merek tersebut mampu mengutamakan kepentingan pihak konsumen ketika masalah dalam konsumsi produk muncul secara tidak terduga.

Dehesti et al. (2016) mengungkapkan bahwa kepercayaan merek berarti nilai merek dapat dibangun dan diperluas melalui pengelolaan beberapa aspek yang berada di luar harapan pelanggan tentang produk dan fitur-fiturnya. Kepercayaan merek dinilai sangat penting karena pengaruhnya terhadap komponen merek lainnya. Utami (2010) menjelaskan kepercayaan terhadap suatu merek dapat mengacu tindakan pembelian ataupun menjadi alasan pihak pembeli untuk melakukan pembelian.

\section{Motivasi Belanja Hedonis}

Motivasi hedonis merupakan adalah motivasi konsumen untuk berbelanja, karena berbelanja merupakan suatu kesenangan tersendiri sehingga tidak memperhatikan manfaat dari produk yang dibeli (Utami, 2010). Motivasi belanja hedonis juga didasari dari dorongan memenuhi kebutuhan psikososial daripada sebagai usaha memperoleh suatu produk belaka. Kebanyakan orang 
berbelanja tidak hanya untuk memenuhi keinginan membeli suatu barang, tetapi juga karena keinginan memperoleh kesenangan tersendiri sat menelusuri tempat perbelanjaan.

Solomon (2018) mengungkapkan bahwa motivasi hedonis dapat menyebabkan reaksireaksi perspektif pengalaman menyoroti gagasan bahwa atribut produk tidak berwujud, seperti desain paket, iklan, nama merek, dan sifat pengaturan dimana pengalaman itu terjadi, dapat membantu membentuk sikap kita terhadap suatu merek. Sari \& Pidada (2019) mengungkapkan motivasi berbelanja hedonis adalah dorongan untuk berbelanja untuk menemukan kesenangan bagi diri sendiri, menghilangkan stres, mengubah suasana hati, dan dapat bersosialisasi dengan teman atau keluarga.

\section{Time Pressure}

Ketersediaannya waktu tentu merupakan suatu hal yang sangat penting dalam suatu perilaku konsumen. Octaprinanta et al. (2013) mengungkapkan waktu dapat menunjukkan berapa lama seseorang konsumen dapat menghabiskan waktunya untuk berada di dalam toko. Baik berbelanja secara online atau offline, terdapat time pressure tersendiri. Pada saat berbelanja melalui website online, terdapat batas waktu pembayaran yang telah ditentukan, seperti konsumen harus melakukan pembayaran pada hari itu juga, atau diberi batas waktu pembayaran untuk pembeliannya.

Seorang konsumen yang memiliki waktu yang cukup senggang berbeda dengan konsumen yang hanya memiliki waktu yang relatif sedikit dalam berperilaku. Sedikitnya waktu yang dimiliki seorang konsumen menimbulkan sebuah tekanan waktu yang menjadi batasan keleluasaan untuk memilih dan berpikir lebih lanjut mengenai produk yang akan dibelinya. Hal ini dapat memicu terjadinya kecenderungan konsumen untuk melakukan pembelian dengan tekanan waktu tersebut, lebih sedikit pertimbangan merek untuk produk yang dibutuhkan. Dengan terbatasnya waktu yang dimiliki seseorang, maka semakin besar pula kemungkinan terjadinya pembelian impulsif.

\section{Promosi}

Perreault et al. (2012) menjelaskan bahwa promosi berkaitan dengan memberi tahu target pasar atau orang lain di saluran distribusi mengenai produk yang "benar". Promosi dapat difokuskan untuk mendapatkan pelanggan baru, maupun mempertahankan pelanggan yang ada saat ini. Promosi meliputi penjualan pribadi, penjualan massal, dan promosi penjualan.

Utami (2010) menyatakan promosi merupakan program mendorong terjadinya penjualan atau upaya untuk meningkatkan penjualan. Kotler \& Keller (2016) menjelaskan bahwa dalam promosi terdapat metodemetode promosi penjualan, periklanan, tenaga penjualan, hubungan masyarakat, maupun pemasaran langsung. Beberapa metode berbeda tersebut digunakan untuk dapat meraih banyak pelanggan.

\section{METODE PENELITIAN}

Penelitian ini bertujuan menjelaskan faktor-faktor yang bisa mendorong konsumen untuk melakukan pembelian impulsif pada saat mengunjungi website dari e-commerce kecantikan di Indonesia. Penelitian ini bertipe eksplorasi, dimana peneliti tidak memiliki pengetahuan simtom yang jelas, seperti faktor atau variabel yang harus ada dalam menilai objek tersebut (Indrawati, 2015). Dalam penelitian ini juga belum dapat dimunculkan hipotesis yang spesifik serta pertanyaan detail. Tipe penyelidikan korelasional pada penelitian ini menggambarkan variabelvariabel penting yang berhubungan dalam suatu masalah penelitian. Kerangka penelitian ini ditunjukkan pada Gambar 2. 


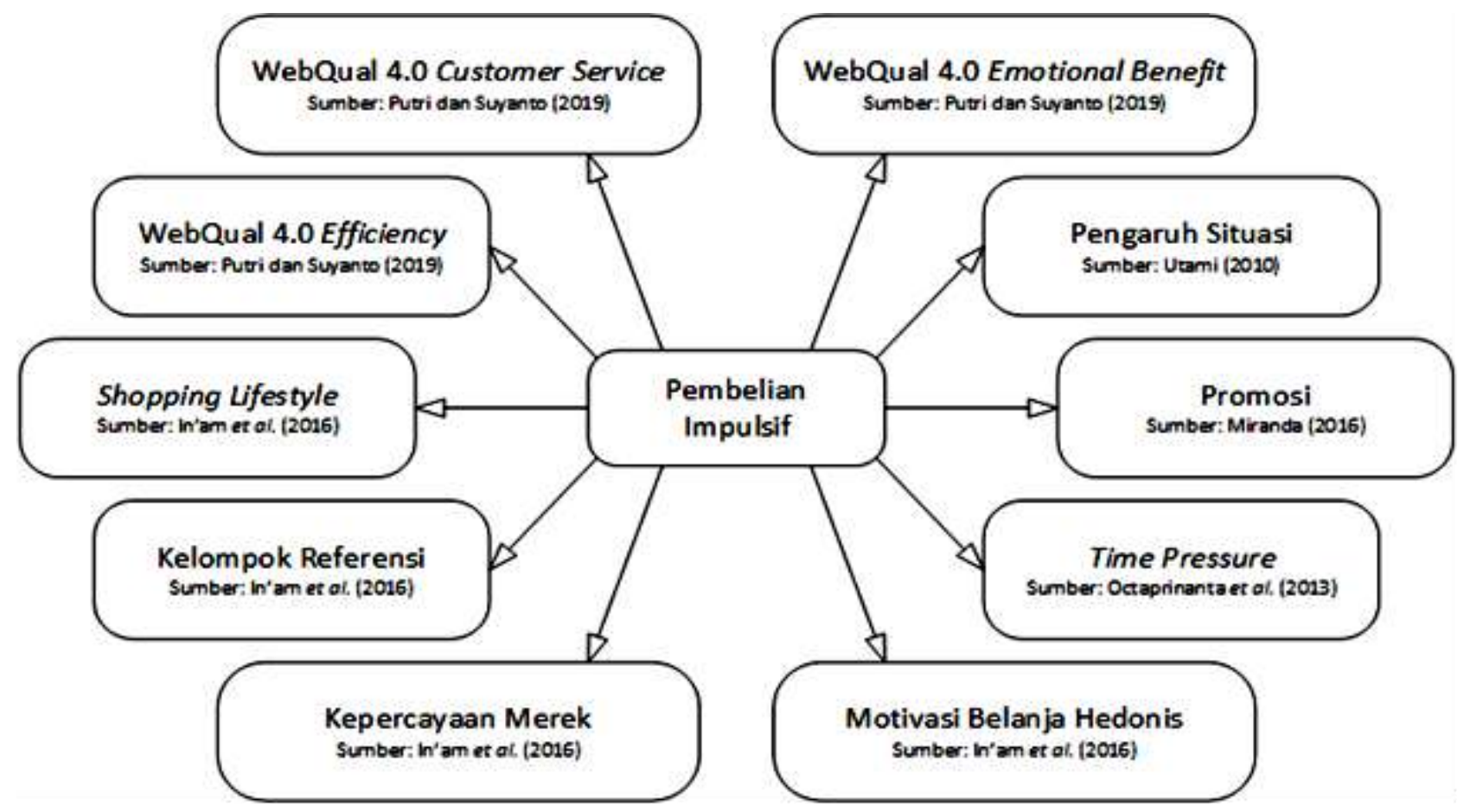

Gambar 2. Kerangka Penelitian

Sumber: Diolah penulis, 2021.

Penelitian kuantitatif ini melakukan pengambilan sampel menggunakan teknik purposive sampling, dimana penentuan sampel berdasarkan beberapa pertimbangan tertentu: (1) konsumen pernah melakukan pembelian pada e-commerce kecantikan di Indonesia; serta, (2) konsumen pernah melakukan pembelian impulsif pada $e$ commerce kecantikan di Indonesia. Informasi ini diketahui melalui pertanyaan awal pada kuesioner. Jumlah responden sebanyak 385 responden diperoleh menggunakan rumus Cochran, dengan alasan jumlah populasi tidak diketahui secara pasti dan sampel yang diambil diseleksi melalui screening questions tertentu terlebih dahulu.

Penelitian ini menganalisis delapan variabel awal yang diduga dapat membentuk pembelian impulsif pada tiga situs $e$ commerce kecantikan di Indonesia, yaitu Sociolla, Beauty Haul Indo dan Sephora Indonesia. Variabel-variabel yang dianalisis meliputi WebQual4.0, shopping lifestyle, kelompok referensi, kepercayaan merek, motivasi belanja hedonis, time pressure, promosi, serta pengaruh situasi.

\section{Metode Analisis Data}

Teknik analisis faktor eksploratori (EFA) digunakan untuk menganalisis hubungan timbal balik di antara sejumlah besar variabel dan untuk menjelaskan variabel-variabel ini dalam istilah "dimensi (faktor)" yang mendasarinya (Sutopo \& Slamet, 2017). Teknik analisis faktor ini ditujukan untuk menemukan faktor-faktor apa saja yang bisa membentuk pembelian impulsif pada e-commerce kecantikan (Charina \& Suyanto, 2019).

Penelitian ini menggunakan analisis faktor bertujuan untuk mengukur reliabilitas dan validitas dari item penelitian. Kriteria nilai minimum merujuk pada riset Zhu et al. (2020) dimana nilai Kaiser-Mayer-Olkin (KMO) harus diatas 0,5. Dalam penelitian ini, analisis data dibantu oleh software SPSS ver. 24 for Windows. 
Tabel 2. Hasil Analisis Deskriptif

\begin{tabular}{llc}
\hline \multicolumn{1}{c}{ Karakteristik Responden } & \multicolumn{1}{c}{ Jenis } & Persentase $(\%)$ \\
\hline Jenis Kota & Kota Besar & 60,5 \\
& Kota Kecil & 20,3 \\
& Kota Metropolitan & 19,2 \\
Jenis Kelamin & Perempuan & 87,5 \\
& Laki-Laki & 12,5 \\
Usia (tahun) & $15-20$ & 12,5 \\
& $21-25$ & 60,3 \\
& $26-30$ & 23,9 \\
Pendapatan per bulan (Rp.) & $>30$ & 3,3 \\
& $1.500 .000-3.000 .000$ & 32,7 \\
& $3.500 .000-5.000 .000$ & 44,9 \\
& $>5.000 .000$ & 14,2 \\
\hline
\end{tabular}

Sumber: Data primer (diolah), 2021.

Proses analisis faktor yang dijalankan mengikuti rekomendasi Sutopo \& Slamet (2017). Proses memiliki tujuh langkah yang dijalankan, yaitu merumuskan masalah bahwa pembelian impulsif kerap terjadi pada $e$ commerce khususnya industri kecantikan; menyusun matriks korelasi dengan mengelompokkan variabel-variabel yang akan menjalani analisis faktor dalam permasalahan; melakukan ekstraksi faktor berbasis variabel laten yang telah ditentukan; merotasi faktor; menginterpretasikan faktor berdasarkan nilai eigenvalue-nya; membuat skor faktor dimana item yang membentuk faktor-faktor yang dikelompokkan berbasis nilai eigenvalue yang berkontribusi pada pembentukan faktor baru, serta, memilih variabel pengganti.

\section{HASIL ANALISIS}

\section{Karakteristik Responden}

Hasil analisis deskriptif pada Tabel 2 menunjukkan bahwa karakteristik responden penelitian ini didominasi para pembeli yang berdomisili atau bertempat tinggal di kota besar (60,5 persen). Selanjutnya, tabel ini juga mengidentifikasi bahwa responden penelitian ini didominasi oleh pembeli berjenis kelamin perempuan (87,5 persen); berusia 21-25 tahun (60,3 persen); dan, memiliki pendapatan per bulan pada rentang antara Rp. 1.500.000,sampai Rp. 3.000.000,- (44,9 persen).

\section{Hasil Analisis Faktor}

Hasil analisis data yang dirangkum dalam Tabel 3 menyatakan berdasarkan nilai eigenvalues dari total variance (Sutopo \& Slamet, 2017), terbentuk 10 faktor baru yang dapat membentuk pembelian impulsif pada situs e-commerce kecantikan di Indonesia.

Faktor pertama adalah kemudahan dan terorganisir, yang memiliki nilai eigenvalue sebesar 11,576 dengan besaran kontribusi 26,922 persen. Faktor kedua yaitu trend produk, dengan memiliki nilai eigenvalue sebesar 3,671 dan besaran kontribusi 8,538 persen. Faktor ketiga adalah customer service, yang memiliki nilai eigenvalue sebesar 2,581 dengan besaran kontribusi 6,003 persen. Faktor keempat yaitu promo, yang memiliki nilai eigenvalue sebesar 2,416 dengan besaran kontribusi 5,620 persen. Faktor kelima adalah kesenangan, yang memiliki nilai eigenvalue sebesar 1,966 dengan besaran kontribusi 4,573 persen. 
Tabel 3. Hasil Analisis Faktor

\begin{tabular}{clrc}
\hline Faktor ke & \multicolumn{1}{c}{ Nama Faktor Baru } & Total & \% of Variance \\
\hline 1 & Faktor Kemudahan dan Terorganisir & 11,576 & 26,922 \\
2 & Faktor Trend Produk & 3,671 & 8,538 \\
3 & Faktor Customer Service & 2,581 & 6,003 \\
4 & Faktor Promosi & 2,416 & 5,620 \\
5 & Faktor Kesenangan & 1,966 & 4,573 \\
6 & Faktor Ketertarikan & 1,753 & 4,076 \\
7 & Faktor Waktu Terbatas & 1,538 & 3,577 \\
8 & Faktor Merek & 1,306 & 3,038 \\
9 & Faktor Motivasi Berbelanja & 1,263 & 2,938 \\
10 & Faktor Rekomendasi & 1,035 & 2,407 \\
\hline \multicolumn{2}{c}{ Total } \\
\hline
\end{tabular}

Sumber: Data primer (diolah), 2021.

Selanjutnya, faktor keenam adalah ketertarikan dengan memiliki nilai eigenvalue sebesar 1,753 dengan besaran kontribusi 4,076 persen. Faktor ketujuh yaitu waktu terbatas, yang memiliki nilai eigenvalue sebesar 1,538 dengan besaran kontribusi 3,577 persen. Faktor kedelapan adalah merek, yang memiliki nilai eigenvalue sebesar 1,306 dengan besaran kontribusi 3,038 persen. Faktor kesembilan adalah motivasi belanja, yang memiliki nilai eigenvalue sebesar 1,263 dengan besaran kontribusi 2,938 persen. Faktor kesepuluh yaitu rekomendasi, yang memiliki nilai eigenvalue sebesar 1,035 dengan besaran kontribusi 2,047 persen.

Total varian yang dapat dijelaskan oleh 10 faktor baru tersebut terhadap variabel yang digunakan adalah 67,692 persen; sementara sisanya yaitu 32,308 persen menyatakan besaran varian tidak dapat dijelaskan oleh variabel tersebut.

\section{Pembahasan}

Hasil analisis faktor yang diperoleh dalam penelitian mengidentifikasi bahwa dari delapan faktor awal yang dievaluasi, diperoleh sepuluh faktor baru yang dinilai dapat mendorong konsumen untuk melakukan pembelian impulsif pada situs e-commerce kecantikan di Indonesia. Kesepuluh faktor baru tersebut adalah kemudahan dan terorganisir; trend produk; customer service; promosi; kesenangan; ketertarikan; waktu terbatas; merek; motivasi berbelanja; serta, rekomendasi. Faktor yang dominan di antara faktor-faktor baru tersebut adalah kemudahan dan terorganisir.

Faktor kemudahan dan terorganisir merupakan ukuran atas kualitas dari halaman web e-commerce terhadap pembentukan pembelian impulsif. Hasil penelitian ini memperoleh hasil yang menjelaskan bahwa halaman web dari e-commerce kecantikan di Indonesia dinilai telah memberikan informasi yang cukup jelas serta terorganisir dengan baik, sehingga dominan menjadi stimulus bagi aktivitas pembelian impulsif. Hasil ini berbeda dengan temuan riset Putri \& Suyano (2019) pada situs e-commerce Shopee bahwa faktor ini dinilai tidak turut membentuk pembelian impulsif dari konsumen.

Faktor trend produk merupakan kondisi dimana produk yang ditawarkan memiliki derajat popularitas lebih besar dibandingkan produk-produk lainnya yang turut ditawarkan pada periode yang bersangkutan. Hasil 
penelitian ini menemukan bahwa produk hot list ini mampu mendorong adanya pembelian stimulus. Penjelasan yang dimunculkan yaitu bahwa para konsumen memiliki pola perilaku pembelian stimulus pada e-commerce kecantikan utamanya kecenderungan mereka membeli setiap mendapatkan tawaran tentang suatu produk flash sale, membeli produk karena sebuah tren, membeli produk dari merek terkenal dan hits, serta seringkali berbelanja untuk mengikuti tren dari skincare atau make-up terbaru. Hasil penelitian ini memperluas temuan-temuan riset Syastra \& Wangdra (2018).

Customer service merupakan bagian dari strategi pemasaran yang berperan sebagai faktor pendukung dalam penjualan suatu produk (Tjiptono, 2015; Firmansyah, 2018). Hasil penelitian ini menemukan faktor customer service dapat mendorong perilaku impulsif konsumen dalam membeli suatu produk. Penerapan faktor ini dalam $e$ commerce kecantikan di Indonesia meliputi halaman situs selalu siap dan bersedia merespon kebutuhan pelanggan, bagian customer service yang selalu cepat dalam merespon pelanggan, pertanyaan dijawab segera oleh customer service, serta perilaku customer service yang ramah.

Hasil penelitian ini juga menemukan bahwa promosi merupakan faktor yang membentuk pembelian implusif. Promosi merupakan upaya pemasaran untuk mencari pelanggan baru sekaligus merawat pelanggan lama sehingga memperluas pasar sekaligus mendorong penjualan (Perreault et al., 2012; Kotler \& Keller, 2016). Hasil ini serupa dengan temuan riset milik Akyuz (2018) serta Syastra \& Wangdra (2018) bahwa faktor promosi mendorong seorang konsumen untuk melakukan pembelian impulsif secara online. Perilaku ini seperti konsumen mengunakan kode voucher untuk mendapatkan potongan harga, membeli karena ada diskon, membeli karena ada promo buy 1 get 1 , ataupun membeli karena ada promo paket bundle.

Penelitian ini memperoleh hasil bahwa faktor kesenangan bisa membentuk pembelian impulsif seorang konsumen dari web ecommerce kecantikan di Indonesia. Faktor ini menjelaskan empat hal, yaitu pengguna atau konsumen menyukai halaman situs tersebut, pengguna merasakan kegembiraan tersendiri dan juga senang ketika mengakses atau mengunjungi halaman situs, serta pengguna merasa senang ketika berbelanja untuk keluarga atau teman melalu situs tersebut. Hasil serupa juga ditemukan Ahmad et al. (2018) dan Zhang et al. (2018) bahwa perilaku kesenangan konsumen melakukan browsing akan menuntun kepada perilaku pembelian impulsif.

Faktor ketertarikan juga ditemukan melalui hasil empiris sebagai pembentuk pembelian impulsif konsumen. Ketertarikan pada kemasan produk ataupun penonjolan unsur tertentu pada produk yang bersangkutan melali website yang dikelola manajemen $e$ commerce kecantikan di Indopnesia bisa mempengaruhi perasaan konsumen yang mengarah pada aktivitas pembelian impulsif (Akyuz, 2018; Khawaja, 2018; Nada \& Wibowo, 2015). Definisi dari ketertarikan dalam penelitian ini meliputi perilaku membeli karena persyaratan pembeliannya dapat dipenuhi, pengguna merasa kebutuhan mendadak dari produk skincare maupun makeup, membeli produk karena merasa tertarik pada saat itu, serta konsumen merasa harus membeli produk pada saat itu juga.

Keterbatasan waktu yang dimiliki konsumen saat berbelanja atau browsing situs e-commerce ditengarai dapat mendorong pembelian impulsif. Hasil penelitian ini mengkonfirmasi bahwa faktor itu berperan membentuk perilaku impulsif konsumen saat berbelanja. Namun demikian, temuan empiris Octaprinanta et al. (2013) menyatakan bahwa 
faktor time pressure tidak membentuk perilaku impulsif tersebut. Dalam penelitian ini, faktor waktu terbatas meliputi terdapatnya kondisi waktu pembayaran yang diberikan sangat terbatas, pengguna membeli produk terburu-buru karena keterbatasannya waktu, serta bahwa pengguna juga membeli produk karena waktu pembayaran yang sangat terbatas.

Faktor merek atau khususnya adalah kepercayaan atas merek (brand trust) merefleksikan keyakinan konsumen bahwa suatu produk melalui fitur-fiturnya mampu memenuhi harapan milik konsumen dengan terpenuhinya janji seperti tersemat dalam website dari pihak pemasarnya (Kotler \& Armstrong, 2014; Dehesti et al., 2016; Utami, 2010). Dalam penelitian ini, faktor merek dinilai menjadi pembentuk perilaku impulsif dari konsumen. Faktor ini menjelaskan kondisi bahwa merek terkenal yang dibeli oleh pengguna berkualitas baik, merek yang dibeli memberikan nilai kepada pengguna, serta juga konsumen membeli produk dari merek yang terkenal.

Motivasi belanja didefinisikan sebagai perilaku karena dorongan psikososial atau kesenangan pribadi saat berbelanja ketimbang upaya memenuhi kebutuhan melalui manfaat dari suatu produk (Utami, 2010; Solomon, 2018). Hasil penelitian ini menemukan bahwa faktor motivasi belanja membentuk perilaku pembelian impulsif dari konsumen. Hasilhasil riset milik Sari \& Pidada (2019) serta In'am et al. (2016) juga menyimpulkan serupa. Faktor motivasi belanja menjelaskan bahwa pihak konsumen merasa berbelanja merupakan satu alternatif untuk mengatasi stress, konsumen lebih senang berbelanja untuk dirinya sendiri, berbelanja merupakan suatu pengalaman spesial, serta konsumen juga lebih suka mencari situs e-commerce kecantikan yang menawarkan harga yang relatif murah.
Hasil terakhir dari penelitian ini menemukan faktor rekomendasi merupakan pembentuk perilaku belanja impulsif. Factor ini bisa diperoleh melalui kelompok referensi yang dijadikan konsumen sebagai asosiasi atau dasar perbandingan berkenaan dengan kepercayaan, perasaan dan perilaku atas suatu produk (Grewal \& Levy, 2018; Kardes et al., 2011). Aragoncillo \& Orus (2017) juga menemukan bahwa faktor rekomendasi utamanya yang berbasis jaringan sosial dapat memicu terjadinya pembelian impulsif. Faktor rekomendasi menjelaskan bahwa konsumen membeli produk sesuai saran dari temannya, memutuskan untuk membeli suatu produk karena saran dari teman, dan juga membeli produk mengacu pada saran dan ulasan kelompok mengenai suatu produk.

Terakhir, berkaitan dengan riset Rizky dan Suyanto (2020) yang berargumen faktorfaktor baru miliknya dapat digeneralisir pada industri layanan penyedia internet. Pada penelitian ini, bagaimanapun, ditemukan bahwa setelah dilakukan validasi ulang dengan melakukan split-half data, didapatkan jumlah faktor yang terbentuk tidak konsisten. Dengan demikian, faktor-faktor baru yang terbentuk dalam penelitian ini tidak dapat digeneralisir pada semua industri e-commerce kecantikan.

\section{SIMPULAN}

Hasil-hasil yang diperoleh di penelitian ini merekomendasikan agar pihak manajemen e-commerce kecantikan untuk dapat terus meningkatkan kemudahan dalam penggunaan website-nya serta terus memperhatikan agar segalanya terorganisir dengan baik, utamanya mengenai informasi mengenai produk. Pihak manajemen sebaiknya juga berupaya bisa meningkatkan bandwidth dari server website, agar konsumen mudah dalam mengakses website dan tidak sering mengalami server down yang dapat menyebabkan website 
membutuhkan waktu lama untuk bisa diakses. Kondisi tersebut tentu membuat konsumen merasa kesal dan akhirnya tidak melakukan pembelian atas produk yang ditawarkan.

Keterbatasan utama pada penelitian ini yaitu periode pelaksanaan penelitian yang dilakukan dengan waktu yang cukup singkat yaitu kurang lebih selama 2 hingga 3 bulan. Untuk mengatasi keterbatasan ini, peneliti selanjutnya disarankan melakukan penelitian dengan rentang waktu yang lebih panjang. Keterbatasan kedua adalah teknik analisis data yang digunakan yaitu faktor eksploratori, sehingga diharapkan pada peneliti selanjutnya untuk mengembangkan kajian dengan metode analisis yang lain, seperti analisis faktor konfirmatori. Peneliti berikutnya juga dapat menambahkan jumlah faktor-faktor lain yang diduga dapat membentuk pembelian impulsif. Selain itu, peneliti selanjutnya juga dapat melakukan penelitian pada objek yang berbeda dengan jenis penelitian lain seperti penelitian kualitatif.

\section{REFERENSI}

Ahmad, M. B., Ali, H. F., Malik, M. S., Humayun, A. A., \& Ahmad, S. (2018). Factors affecting impulsive buying behavior with mediating role of positive mood: An empirical study. European Online Journal of Natural and Social Sciences, 8(1), 17-35. Retrieved from http://european-science.com/eojnss/ article/download/5510/2617.

Akyuz, A. (2018). Determinant factors influencing impulse buying behavior of Turkish customers in supermarket setting. Business and Social Science IJRBS, 7(1), 1-10. doi: 10.20525/ijrbs.v7i1.839.

Aninda, N. (2020). Prospek gemilang bisnis ecommerce produk kecantikan, [online]. Retrieved from https://entrepreneur. bisnis.com/read/20200723/88/1270399/pr ospek-gemilang-bisnis-e-commerceproduk-kecantikan (8 November 2020).
Aragoncillo, L., \& Orús, C. (2017). Impulse buying behaviour: an online-offline comparative and the impact of social media. Comportamiento de compra impulsiva: comparativa online-offline e impacto de las redes sociales. Spanish Journal of Marketing, 22(1), 42-62. doi: 10.1108/SJME-03-2018-007.

Charina, D., \& Suyanto, AMA. (2019). Analisis faktor-faktor yang membentuk enterpreneurial intention para generasi muda untuk menjadi young entrepreneur. Jurnal Manajemen dan Bisnis, 3(1), 125133. Retrieved from https://media. neliti.com/media/publications/284343analisis-faktor-faktor-yang-membentuken-e2afb6a7.pdf.

Dehesti, M., Faroujzah, J. A., \& Alimohammadi, H. (2016). The relationship between brand image and brand trust in sporting goods consumers. Annals of Applied Sport Science, 4(3), 27-34. doi: 10.18869/acadpub.aass journal.4.3.27.

Finansialku. (2013). Impulsive buying (Pembelian impulsif) + Solusinya. [online]. Retrieved from https://www.finansialku. com/impulsive-buying-pembelianimpulsif-solusinya/ (23 Maret 2020).

Firmansyah, M. A. (2018). Perilaku konsumen (Sikap dan pemasaran). Deepublish.

Grewal, D., \& Levy, M. (2018). Marketing, $6^{\text {th }}$ Edition. McGraw-Hill.

In'am, M. F., Suharyono., \& Yulianto, E. (2016). Analisis faktor-faktor yang berpengaruh terhadap pembelian impulsif (Survei pada pengunjung yang melakukan pembelian impulsif di Distro 3Second Cabang Mall Olympic Garden Malang). Jurnal Administrasi Bisnis (JAB), 36(1), 92-100. Retrieved from http://administrasibisnis.studentjournal.ub .ac.id/index.php/jab/article/view/1399.

Indrawati. (2015). Metode penelitian manajemen dan bisnis: Konvergensi teknologi komunikasi dan informasi. Refika Aditama. 
Japarianto, E., \& Sugiharto, S. (2011). Pengaruh lifestyle dan fashion involvement terhadap impulse buying behavior masyarakat high income Surabaya. Jurnal Riset Ekonomi dan Manajemen, 18(2), 53-69. doi: 10.9744/pemasaran. 6.1.32-41.

Kardes, F. R., Cronley, M. L., \& Cline, T. W. (2011). Consumer Behavior. Cengage Learning.

Khawaja, L. (2018). Factors influencing consumer buying behavior toward impulse buying. The International Journal of Business \& Management, 6(6), 245-258. Retrieved from http://www.internationaljournalcorner.c om/index.php/theijbm/article/view/131 325 .

Kosyu, D. A., Hidayat, H., \& Abdillah, Y. (2014). Pengaruh hedonic shopping motives terhadap shopping lifestyle dan impulse buying (Survei pada pelanggan outlet Stradivarius di Galaxy Mall Surabaya). Jurnal Administrasi Bisnis, 14(2), 1-7. Retrieved from http://administrasibisnis.studentjournal. ub.ac.id/index.php/jab/article/view/597/ 796.

Kotler, P., \& Armstrong, G. (2014). Principles of marketing, $15^{\text {th }}$ ed. Pearson Education Limited.

Kotler, P., \& Keller, K. L. (2016). Manajemen pemasaran, $13^{\text {th }}$ ed. Penerbit Erlangga.

Laksana, K. A. P., \& Suparna, G. (2015). Peran motivasi hedonis memediasi pengaruh sifat materialisme terhadap perilaku pembelian impulsif secara online. E-Jurnal Manajemen Unud, 4(6), 1661-1675. Retrieved from https://ojs.unud.ac.id/index.php/Manaje men/article/view/12299.

Lee, J., \& Lee, Y. (2019). Does online shopping make consumers feel better? Exploring online retail therapy effects on consumers' attitudes towards online shopping malls. Asia Pacific Journal of Marketing and Logistics, 31(2), 464479. doi: 10.1108/apjml-06-2018-0210.
Levy, M., \& Weitz, B. (2012). Retailing management, $7^{\text {th }}$ ed. McGraw-Hill/ Irwin.

Miranda, Y. C. (2016). Kajian terhadap faktor yang mempengaruhi impulse buying dalam online shopping. Competence Journal of Management Studies, 10(1), 63-76. Retrieved from https://journal. trunojoyo.ac.id/kompetensi/article/view/3 424.

Mulyono, F. (2013). Faktor demografis dalam perilaku pembelian impulsif. Jurnal Administrasi Bisnis Center for Business Studies, 8(1), 92-109. Retrieved from http://journal.unpar.ac.id/index.php/ JurnalAdministrasiBisnis/article/view/ 416.

Nada, N. Q., \& Wibowo, S. (2015). Pengukuran kualitas layanan sistem informasi akademik menggunakan metode Webqual 4.0. Jurnal Informatika Upgris, 1(2), 122-131. doi: 10.26877/jiu.v1i2\% 20Desember.870.

Nia, R. M., \& Shokouhyar, S. (2020). Analyzing the effects of visual aesthetic of Web pages on users' responses in online retailing using the VisAWI method. Journal of Research in Interactive Marketing, 14(4), 357-389. doi: 10.1108/jrim-11-2018-0147.

Octaprinanta, N., Kumadji, S., \& Hidayat, K. (2013). Pengaruh faktor situasional terhadap emotional states dan impulse buying: Survei pada pengunjung Giant Hypermarket Mall, Olympic Garden Malang. Jurnal Administrasi Bisnis S1 Universitas Brawijaya, 5(1), September. Retrieved from http:// administrasibisnis.studentjournal.ub.ac.id /index.php/jab/article/view/224.

Pamungkas, R., \& Saifullah. (2019). Evaluasi kualitas website program studi sistem informasi Universitas PGRI Madiun menggunakan WebQual 4.0. Intensif: Jurnal Ilmiah Penelitian dan Penerapan Teknologi Sistem Informasi, 3(1), 22-31. doi: 10.29407/intensif.v3i1.12137. 
Perreault, W. D., Cannon, J. P., \& McCarthy, E. J. (2012). Essentials of marketing a marketing strategy planning approach, $13^{\text {th }}$ ed. McGraw-Hill/Irwin.

Putri, A. N., \& Suyanto, AMA. (2019). Analisis faktor-faktor pembelian impulsif pada Shopee. e-Proceeding of Management, 6(3), 5510-5516. Retrieved from https://openlibrary.telkomuniversity.ac.id /home/catalog/id/155846/slug/analisisfaktor-faktor-pembelian-impulsif-padashopee.html.

Rizky, C. G., \& Suyanto, AMA. (2020). Analisis faktor-faktor yang membentuk loyalitas pelanggan Indihome dengan layanan triple play di Kota Jakarta. Jurnal Mitra Manajemen (JMM Online), 4(2), 206-2014. doi: 10.52160/ejmm. v4i2.340.

Salsabila, S. N., \& Suyanto, AMA. (2020). Analisis pemetaan e-commerce kecantikan berdasarkan brand equity. Jurnal Mitra Manajemen (JMM Online), 4(2), 293-301. Retrieved from http://www.e-jurnalmitramanajemen. com/index.php/jmm/article/view/347/299

Sari, D. M. F. P., \& Pidada, I. A. I. (2019). Hedonic shopping motivation, shopping lifestyle, price reduction toward impulse buying behavior in shopping center. International Journal of Business, Economics \& Management, 3(1), 48-54. doi: 10.31295/ijbem.v3n1.114.

SimilarWeb. (2020). sociolla.com [Infographic, online]. Retrieved from https://www. similarweb.com/website/sociolla.com (16 Maret 2020).

Sirclo. (2020). Menilik tren perkembangan ecommerce Indonesia di 2020. [online]. Retrived from https://www.sirclo.com/ menilik-tren-perkembangan-ecommerce-indonesia-di-2020/ (7 Oktober 2020).

Solomon, M. R. (2018). Consumer behavior: Buying, having and being, $12^{\text {th }}$ ed. Pearson Education Limited.

Sosianika, A., \& Juliani, N. (2017). Studi tentang perbedaan perilaku pembelian impulsif berdasarkan karakteristik konsumen. Sigma-mu (Jurnal Penelitian \& Gagasan Sains Dan Matematika Terapan), 9(1), 9-18. Retrieved from https://jurnal.polban.ac.id/ojs-3.1.2/sigma mu/article/view/965.

Sutopo, E. Y., \& Slamet, A. (2017). Statistika inferensial. Penerbit ANDI.

Syastra, M. T., \& Wangdra, Y. (2018). Analisis online impulse buying dengan menggunakan framework SOR. Jurnal Sistem Informasi Bisnis, 8(2), 133-140. doi: 10.21456/vol8iss2pp133-140.

Tjiptono, F. (2015). Strategi pemasaran, edisi 4. Penerbit ANDI.

Utami, C. W. (2010). Manajemen ritel: Strategi dan implementasi operasional bisnis ritel modern di Indonesia, $2^{\text {nd }}$ ed. Salemba Empat.

We Are Social and Hootsuite. (2021). Hootsuite (We are social): Indonesian digital report 2020. [online]. Retrieved from https:// andi.link/hootsuite-we-are-socialindonesian-digital-report-2020/ October 2020).

Wibowo, A. (2020). Indonesian skincare ecommerce market trends [online]. Retrieved from https://janio.asia/sea/ indonesia/indonesia-skincareecommerce-trends/ (8 November 2020).

Yoon, S. J. (2012). Antecedents and consequences of in-store experiences based on an experiential typology. European Journal of Marketing, 47(5/6), 693-714. doi: 10.1108/0309056131130 6660.

Zhang, K. Z. K., Zhao, S. J., Cheung, C. M. K., \& Lee, M. K. O. (2014). Examining the influence of online reviews on consumers' decision-making: A heuristic-systematic model. Decision Support Systems, 67, 78-89. doi: 10.1016/j.dss.2014.08.005.

Zhu, W., Yan, R., \& Ding, Z. (2020). Analysing impulse purchasing in cross-border electronic commerce. Industrial Management \& Data Systems, 120(10), 1959-1974. doi: 10.1108/IMDS-01-2020-0046. 